(C) 1984 ISIJ 低・中炭素鋼の疲労特性と静的強化機構 との関連

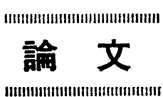

阿部 隆*

\title{
Quantitative Correlation of Static Strengthening Mechanisms to Fatigue Property in Low and Medium Carbon Steels
}

\author{
Takashi AвE, Tetsuya SAmpeI, Hirotada Osuzu and Isao Kozasu
}

\begin{abstract}
Synopsis :
Despite of ferrite pearlite structure, microalloyed and controlled rolled bar revealed good fatigue property almost equivalent to quenched and tempered plain carbon steels whose microstructure was tempered martensite. Detailed study was carried out to give a comprehensive interpretation for this phenomenon. The relation between static strengthening mechanisms and fatigue property was investigated quantitatively, using low and medium carbon steels conventionally or controlled rolled with variation of $\mathrm{Si}$ and $\mathrm{Mn}$ contents and $\mathrm{V}$ or $\mathrm{Nb}$ additions. As a result of this, it was clarified that each strengthening mechanism showed different contribution in improving fatigue limit. Compared with grain refinement, pearlite and dislocation strengthening, both solid solution and precipitation strengthening improved fatigue limit efficiently as well as dispersion strengthening. This was caused by their effectiveness both in preventing dislocation from migration under cyclic loading and in strengthening ferrite matrix comparatively uniformly.
\end{abstract}

\section{1. 緒言}

析出強化元素の利用あるいは場合によつてはそれとと もに制御圧延を施す非調質型機械構造用棒鋼は近年棒鋼 製造分野において注目されるものの一つである.これは 圧延ままのフェライト・パーライト組織を有する状態で 優れた強度あるいは靱性を示すことの他に従来の調質材 と同等ないしはそれ以上の疲れ特性を示すことによる1). 一般に炭素鋼は調質処理を行い焼もどしマルテンサイト 組織とした方が良好な疲れ限度比を示すとされるが，非 調質鋼にみられる前述の現象はこのような通例では説明 し得ないものであるといえる。

このような現象に対し従来より多くなされているミク 口組織的な因子を考虑した立場からの疲労研究が有用な 解釈を与えるものとして期待される．例えば，疲労特性 向上因子を明らかにするため疲労特性と静的強度の関係 について検討したものがあり, 摩擦応力の大小が関与し ているとするもの2)や，あるいはそれをさらに強化機構 に分類して解析を行つたものなどがみられる32 5). しか しながら，それらは疲労特性に刘するそれぞれの強化機 構の良否を定性的に論じたものや，あるいは定量的検討
に至つているものでも特定の強化機構のみに着目したも のが多い、また，必ずしも一致した結果が得られていな いのが現状といえる.

このような背景のもとに本研究では疲労特性に対する より本質的な影響因子を探る目的で（1)種々の成分・ 処理を施した広範な鋼種に対し静的強度と疲労特性の関 連を把握したらえで, (2)静的強度を析出強化, 固溶強 化などの強化機構別に 精確に定量化し, 次に (3)静的 強度を構成する因子がどのように疲労特性と関係してい るかを定量的に議論することを試みる。これにより疲労 特性の機構解明に手掛かりを与えるとともに, 特性向上 のための具体的方策を明らかにし非調質鋼の優れた疲労 特性の機構について説明を与えることを最終的な目的と している.

\section{2. 供試鋼および実験方法}

Table 1 に供試鋼の化学成分を示す.これらを分類す ると（1）炭素量を $0.1 〜 0.55 \%$ まで変化させた通常炭 素鋼（2) $0.1 \sim 0.3 \% \mathrm{G}$ 炭素鋼に $0.1 \% \mathrm{~V}$ を添加したV 添加鋼 (3) $0.1 \% \mathrm{G}$ 炭素鋼に $1.0 \% \mathrm{Si}, 1.9 \% \mathrm{Mn}$ 添加 した鋼（4) 厚板などに用いられる Nb添加した HSLA

眧和 57 年 9 月本会講演人会にて発长 眧和 58 年 12 月 2 日受付 (Received Dec. 2, 1983)

* 日本鋼管 (株) 中央研究所 (Technical Research Center, Nippon Kokan K. K., 1-1 Minamiwatarida-cho Kawasaki-ku Kawasaki 210)

*2 日本鋼管(株) 中央研究所 (現：(㧣) 啠嬬製鋼所) (Technical Research Center, Nippon Kokan K. K., Now Azuma Steel Co., Ltd.)

*3 日本鋼管(株) 中央研究所工博 (Technical Research Center, Nippon Kokan K. K.) 
Table 1. Ghemical compositions (wt $\%$ ).

\begin{tabular}{|c|c|c|c|c|c|c|c|c|c|c|c|}
\hline & Steel & G & $\mathrm{Si}$ & $\mathrm{Mn}$ & $\mathbf{P}$ & $\mathrm{S}$ & $\mathrm{Cr}$ & $\mathrm{Nb}$ & $\mathrm{V}$ & Sol.Al & $\mathrm{T} . \mathrm{N}$ \\
\hline Plain carbon steels & $\begin{array}{l}\mathrm{A} \\
\mathrm{B} \\
\mathrm{C} \\
\mathrm{D} \\
\mathrm{E} \\
\mathrm{F}\end{array}$ & $\begin{array}{l}0.10 \\
0.19 \\
0.25 \\
0.29 \\
0.46 \\
0.55\end{array}$ & $\begin{array}{l}0.14 \\
0.19 \\
0.23 \\
0.19 \\
0.25 \\
0.27\end{array}$ & $\begin{array}{l}0.66 \\
0.70 \\
0.63 \\
0.70 \\
0.62 \\
0.68\end{array}$ & $\begin{array}{l}0.007 \\
0.006 \\
0.016 \\
0.007 \\
0.015 \\
0.007\end{array}$ & $\begin{array}{l}0.004 \\
0.004 \\
0.027 \\
0.005 \\
0.026 \\
0.023\end{array}$ & $\begin{array}{l}\mathrm{tr} \\
1 " \\
1 " \\
11 \\
1 " \\
\prime \prime\end{array}$ & $\begin{array}{l}\mathrm{tr} \\
\prime \prime \\
\prime \prime \\
\prime \prime \\
" \prime \\
" \prime\end{array}$ & $\begin{array}{l}\mathrm{tr} \\
\text { "1 } \\
1 " \\
11 \\
\text { "' }\end{array}$ & $\begin{array}{l}0.021 \\
0.020 \\
0.018 \\
0.025 \\
0.022 \\
0.024\end{array}$ & $\begin{array}{l}0.0057 \\
0.0066 \\
0.0083 \\
0.0060 \\
0.0095 \\
0.0089\end{array}$ \\
\hline $\mathrm{V}$ contained steels & $\begin{array}{c}\mathbf{G} \\
\mathbf{H} \\
\mathbf{I}\end{array}$ & $\begin{array}{l}0.10 \\
0.20 \\
0.29\end{array}$ & $\begin{array}{l}0.14 \\
0.19 \\
0.20\end{array}$ & $\begin{array}{l}0.57 \\
0.66 \\
0.67\end{array}$ & $\begin{array}{l}0.006 \\
0.006 \\
0.007\end{array}$ & $\begin{array}{l}0.004 \\
0.004 \\
0.005\end{array}$ & $\begin{array}{l}\operatorname{tr} \\
\prime \prime \\
\prime \prime\end{array}$ & $\begin{array}{l}\mathrm{tr} \\
\prime \prime \\
\prime \prime\end{array}$ & $\begin{array}{l}0.09 \\
0.10 \\
0.10\end{array}$ & $\begin{array}{l}0.021 \\
0.024 \\
0.022\end{array}$ & $\begin{array}{l}0.0058 \\
0.0069 \\
0.0061\end{array}$ \\
\hline $\mathrm{Nb}$ contained steels & $\begin{array}{l}\mathrm{J} \\
\mathrm{K} \\
\mathrm{L}\end{array}$ & $\begin{array}{l}0.24 \\
0.34 \\
0.45\end{array}$ & $\begin{array}{l}0.29 \\
0.28 \\
0.33\end{array}$ & $\begin{array}{l}0.94 \\
0.97 \\
1.00\end{array}$ & $\begin{array}{l}0.019 \\
0.021 \\
0.021\end{array}$ & $\begin{array}{l}0.003 \\
0.002 \\
0.002\end{array}$ & $\begin{array}{l}\mathrm{tr} \\
\prime \prime \\
\prime \prime\end{array}$ & $\begin{array}{l}0.031 \\
0.036 \\
0.034\end{array}$ & $\begin{array}{l}\mathrm{tr} \\
\prime \prime \\
\prime \prime\end{array}$ & $\begin{array}{l}0.022 \\
0.024 \\
0.025\end{array}$ & $\begin{array}{l}0.0064 \\
0.0059 \\
0.0074\end{array}$ \\
\hline $\mathrm{Si}, \mathrm{Mn}$ increased steels & $\begin{array}{l}\mathrm{M} \\
\mathrm{N}\end{array}$ & $\begin{array}{l}0.12 \\
0.11\end{array}$ & $\begin{array}{l}1.02 \\
0.27\end{array}$ & $\begin{array}{l}0.75 \\
1.86\end{array}$ & $\begin{array}{l}0.007 \\
0.007\end{array}$ & $\begin{array}{l}0.004 \\
0.004\end{array}$ & $\mathrm{tr}_{11}$ & $\underset{\prime \prime}{\mathrm{tr}}$ & $\stackrel{\operatorname{tr}}{\prime \prime}$ & $\begin{array}{l}0.024 \\
0.015\end{array}$ & $\begin{array}{l}0.0061 \\
0.0058\end{array}$ \\
\hline HSLA* steels & $\begin{array}{l}\mathrm{O} \\
\mathbf{P}\end{array}$ & $\begin{array}{l}0.16 \\
0.11\end{array}$ & $\begin{array}{l}0.28 \\
0.35\end{array}$ & $\begin{array}{l}1.33 \\
1.52\end{array}$ & $\begin{array}{l}0.016 \\
0.011\end{array}$ & $\begin{array}{l}0.008 \\
0.005\end{array}$ & ${ }_{0.18}^{\operatorname{tr}}$ & $\begin{array}{l}0.024 \\
0.043\end{array}$ & $\begin{array}{c}\mathrm{tr} \\
0.07\end{array}$ & $\begin{array}{l}0.019 \\
0.025\end{array}$ & $\begin{array}{l}0.0057 \\
0.0060\end{array}$ \\
\hline PII** & $Q$ & 0.01 & $\operatorname{tr}$ & 0.07 & 0.007 & 0.002 & $\operatorname{tr}$ & $\operatorname{tr}$ & $\operatorname{tr}$ & 0.002 & 0.0060 \\
\hline
\end{tabular}

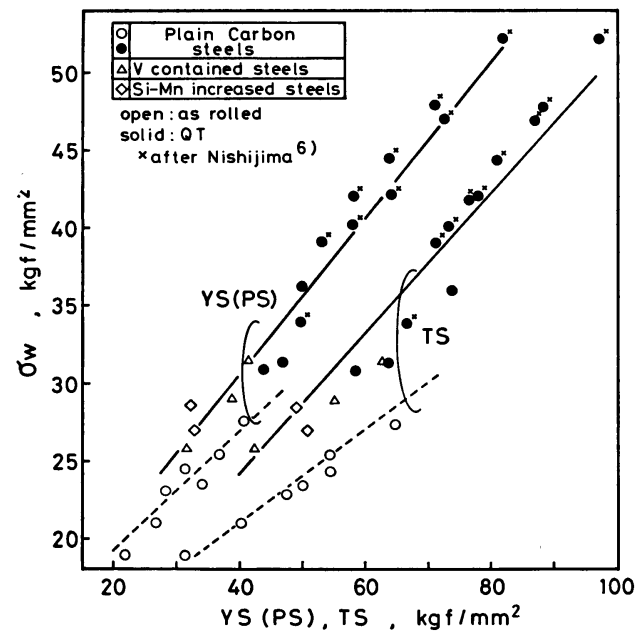

Fig. 1. Relation between static tensile properties and fatigue limit of various steels.

(High Strength Low Alloy) 鋼 (5) 工業用純鉄の 5 つ のグループに分かれる.これらの供試鋼のうち $\mathrm{O}, \mathrm{P}, \mathrm{Q}$ 鋼は転炉出鋼材でありその他は実験室溶製したものであ る. これらを分塊圧延後 $1100^{\circ} \mathrm{C}$ に再加熱し実験室材に ついては板厚 $20 \mathrm{~mm}$ の板圧延, 一方転炉材は棒鋼ミル で連続圧延を行い $\phi 28 \mathrm{~mm}$ の丸棒とした. 一部の供試 鋼については通常圧延の他に細粒化を目的として仕上が り温度を $900^{\circ} \mathrm{C}, 800^{\circ} \mathrm{C}$ に低下させる制御圧延を字施 した. 仕上がり温度の調整は板圧延の場合パス間時間,

棒鋼ミルの場合には圧延速度とスタンド間における冷却 水量を変化させることで行つた。

さらに圧延後に粒径および析出強化量を調整する目的 で $900^{\circ} \mathrm{C} \times 60 \mathrm{~min}$ 保持後空冷の焼ならし処理を, また
は焼もどしマルテンサイト組織とする目的で $900^{\circ} \mathrm{C} \times$ $60 \mathrm{~min}$ 保持水冷 $-600^{\circ} \mathrm{C} \times 60 \mathrm{~min}$ 保持水冷の調質処理を 一部の通常圧延材について施した. 工業用純鉄について は压延ままの他に加工硬化を与えるために減面率 Re. $=20,40 \%$ にて冷間引き抜きを行い冷閒加工を加えた

以上の試料調整を行つた後, 平行部 $10 \mathrm{~mm}$ の回転曲 げ疲労試験片およびJIS 4 号引張り試験片を压延方向に 採取し試験に供した. 回転曲げ疲労試験により SN 曲綿 を作製し，この SN 曲線から疲労特性を代表するものと して疲れ限度 $\sigma_{\mathrm{w}}$ を求め静的強度との検討に用いた。な お, 本研究での疲れ限度は繰り返し数 $10^{7}$ 回を基準とし て JIS Z 2274 に定められた方法によつて求めた.

また，ミクロ組織の定量としてリニアル・アナライサ を用いフェライト粒径, パーライト体積分率を, 電顕勧 察によりパーライトのラメラ間隔を求め解析に用いた.

\section{3. 実 験 結 果}

\section{1 疲れ限度と降伏応力, 引張強さとの比較}

Fig. 1 に通常圧延材, 焼入れ焼もどし材の疲れ限度 $\sigma_{\mathrm{w}}$ を降伏応力 (下降伏点: YS), 引張強さ (TS) と。 関係として示す.なお, 図中には疲れデータシート6) S35C～S55C に対する值を参照して図示してある（この 場合の降伏応力は $0.2 \%$ 耐力). 本実験の圧延材は炭素 量を変化させた炭素鋼と析出強化を図つたV添加鋼およ び $\mathrm{Si}, \mathrm{Mn}$ を増量して固溶強化量を変化させたものに 分かれる.

いずれの鋼種も静的強度の増加に伴い疲れ限度も増し ていることがわかるが，例えばTS との比較でみると炭 素鋼の压延まま材とその他の鋼種との間に明瞭な層別か あることが認められる.すなわち，一般に知られている 
よらに圧延まま材に比べこれを焼入れ焼もどししたもの の方が疲れ限度比 $\left(\sigma_{\mathrm{w}} / \mathrm{TS}\right)$ が向上している.ささら 圧延まま材の中で比較するとV添加鋼あるいは $\mathrm{Si}, \mathrm{Mn}$ を増加した鋼の方が炭素鋼に比べ同一強度であつても 20〜 30\% 程度高い疲れ限度を示している. この值は炭 素鋼の焼入れ焼もどし材に相当することがうかがえる が，これは前述した非調質鋼でみられたものと同様な傾 向といえる. 压延まま材はいずれもフェライト・パーラ イト組織を呈しており同一のミクロ組織であつても疲れ 限度比が異なることを Fig. 1 の結果は示している.す なわち, 同じミクロ組織においても析出強化量や固溶強 化量を変化させ静的強度を構成する強化因子を調整する と TSのみでは疲学特性が整理されないことを以上のこ とは示している.

一方, YS との関係はTS の場合に比べて鋼種間の差 異が幾分緩和されている. しかしながら，この場命にお いても必ずしも種々の鋼種が合致した関係で表されてお らずTS の場合と同様強化機構によつて疲労特性への影 響が異なることが示唆されている. 従つて，より本質的 にはYS を各強化機構別に分類し疲労特性に対するそれ ぞれの影響を明らかにする必要があるといえる。

\section{2 各種処理による疲労特性変化}

$3 \cdot 2 \cdot 1$ 焼ならしによる特性変化

V添加鋼を用い玨延後焼ならしを施すことにより析出 強化量を調整しそれに伴う各特性の変化を調查した，薄 膜による電顕観察により圧延ままでは $100 \AA$ 以下の微細 析出物の列状析出が認められており, さらに微細な析出 物の整合析出が起こつていると思われる.これに対し焼

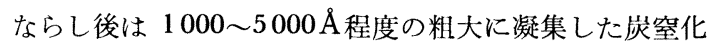
物が観察され，よく知られているよらに焼ならしにより 炭窒化物の凝集・粗大化が起こつていることが確かめら れた。焼ならしに伴らこのような析出形態の変化により 析出強化量は Fig. 2 に示されるよらに $4 \sim 8 \mathrm{kgf} / \mathrm{mm}^{2}$ 程度減少し疲れ限度も図中に破線で示される傾向で低下 する.V添加鋼の焼ならし後の YS と $\sigma_{\mathrm{w}}$ との関係は 炭素鋼のそれとほぼ同水準であり，压延ままの場合に認 められたV添加鋼の優位性が焼ならし後には消失するこ とが示されている.これは炭素鋼にみられる変化と対照 的である.

なお，図中には疲れデータシート6)を参照して S25C 焼ならし材に対する值が同時に図示されている。

Fig. 2 は析出強化量の増減が疲労特性と密接に関係 するものであることを示すといえる.また，V添加鋼の YS と $\sigma_{\mathrm{w}}$ の関係が焼ならしにより変化する際の傾きは 炭素鋼のそれと比べてかなり大きい。炭素鋼においては

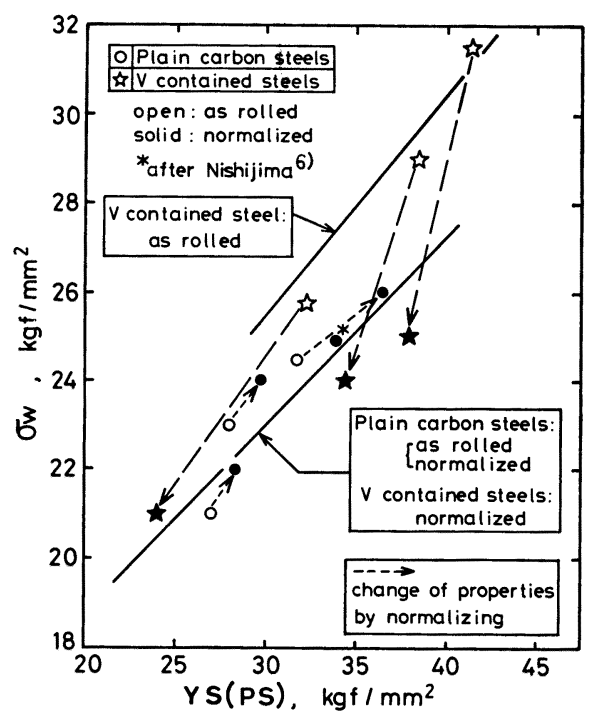

Fig. 2. Variation of yield stress and fatigue limit by normalizing.

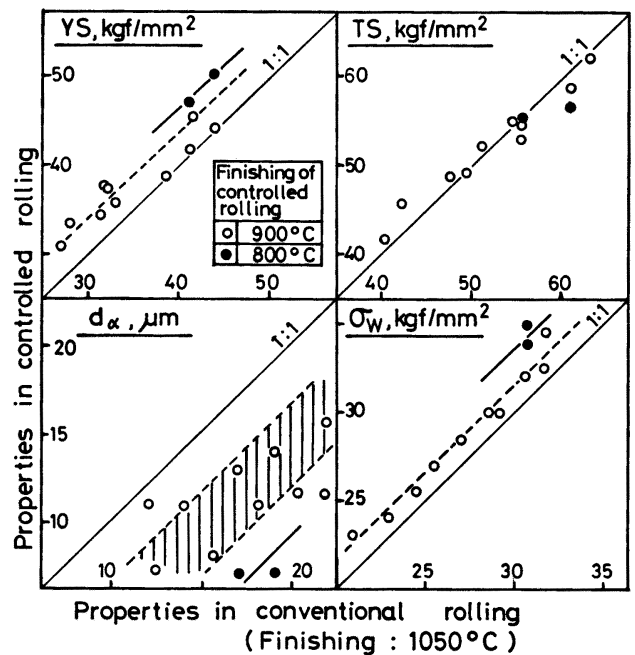

Fig. 3. Change of mechanical properties and microstructure by finishing temperature.

主に炭素量を変えてパーライト体積分率の増減により強 度が調整されている. 従つて, 疲労特性への関与の仕方 は析出強化の場合と炭素量を変えた場合とでは異なつて おり，析出強化の方がより有利に作用していることが Fig. 2 により示唆される.

$3 \cdot 2 \cdot 2$ 制御圧延による特性変化

本節では仕上がり温度を変えて制御圧延を施すことに より疲労特性がどのように変化するかを求めた。その主 たる目的は析出強化量等, 他の強化量を一定としたまま 
で粒径のみ 変化させた場合の 影響を 検討することにあ る. Fig. 3 に炭素鋼，V添加鋼，HSLA 鋼など 10 鋼 種について制御圧延を行つた場合のフェライト粒径，機 械的特質, 疲労特性の变化を通常圧延材の場合と比較し て示す. 制御圧延の特徵である細粒化がここでも確認さ れ，仕上がり温度が $900^{\circ} \mathrm{C}$ で通常圧延材の $50 \sim 80 \%$, $800^{\circ} \mathrm{C}$ 仕上がりでは $40 \%$ 程度にまでフェライト粒径の 細粒化が起こつている．YS はいずれの鋼種も各仕上が り温度に対し $3 \sim 4 \mathrm{kgf} / \mathrm{mm}^{2}$ 抢よび $6 \mathrm{kgf} / \mathrm{mm}^{2}$ 上昇し ているが，TS には傾向的な変化はみられない，一方， 疲れ限度は通常圧延材に比べ $900^{\circ} \mathrm{G}$ 仕上がり材で 1 〜 $2 \mathrm{kgf} / \mathrm{mm}^{2}, 800^{\circ} \mathrm{C}$ 仕上がり材で $3 \sim 4 \mathrm{kgf} / \mathrm{mm}^{2}$ 程度増 加している. 従つて，制御圧延による細粒化に起因した YS の上昇が疲労特性の向上に結びついているといえ る.この場合も疲労特性はTSよりむしろ YS の変化と 対応を示している.

$3 \cdot 2 \cdot 3$ 冷間加工による特性変化

加工硬化の疲労特性におよぼす影響を調べるため工業 用純鉄に冷間加工を施し特性值の変化を調査した。薄膜 観察により減面率の増大とともに転位密度が急増し減面 率 $20 \%$ で既にセル組織が形成されること, さらに減面 率 $40 \%$ ではこの傾向がより顕著になるとともに加工方 向に並んだ下部組織を呈することが認められた。このよ うな転位の増殖により転位強化が生ずるが，減面率 10 $\%$ 当たり $5 \sim 10 \mathrm{kgf} / \mathrm{mm}^{2}$ の静的強度の増加およびそれ に伴う疲れ限度の上昇が認められた。これを YS と $\sigma_{\mathrm{w}}$ の関係として整理すると Fig. 4 のように示される.こ の場合にも YS と $\sigma_{\mathrm{w}}$ は良い直線関係を示すことがわ かる.しかし, 同時に図示した炭素鋼の場合と比べると 冷間加工材の結果はこれと同一直線で整理されず下側に 位置している.Fig. 4 は $3 \cdot 2 \cdot 1$ 節で得られた結果と同

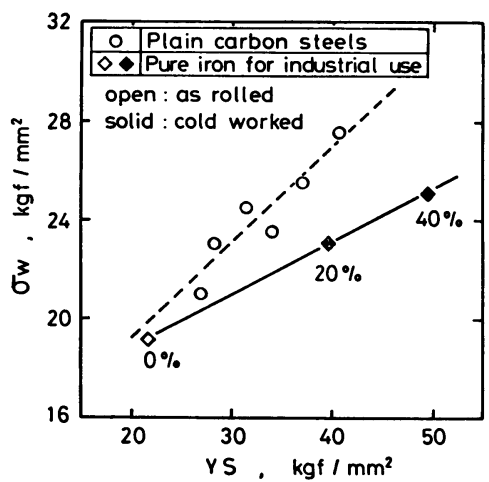

Fig. 4. Variation of yield stress and fatigue limit with cold drawing in pure iron for industrial use. $(0.01 \% \mathrm{C}-0.07 \% \mathrm{Mn})$
様に強化機構が異なると疲労特性への影響度が変わると いらことを表するのであり，冷間加工による転位強化の 方がパーライト量を変えた場合に比べ疲労特性への寄与 が低いことを示唆している.

\section{$3 \cdot 3$ 静的強化機構の解析}

前節までの結果は強化機構により疲労特性への影響が 異なることを示唆するものであり強化機構に分類して疲 労特性の検討を行ら必要のあることを示している．そこ で本節ではまずその検討の基礎となる静的強化機構の解 析を行つた.

パーライト体積率がかなり高い場合まで含めたフェラ イト・パーライト組織において一般的に YS は (1) 式で 示されるよらな強化機構により構成される.

$$
\sigma_{\mathrm{y}}=\sigma_{\mathrm{yo}}+\sigma_{\mathrm{ss}}+\sigma_{\mathrm{ppt}}+\sigma_{\mathrm{prlt}}+\sigma_{\mathrm{dis}}+K \cdot d^{-1 / 2}
$$

ここで $\sigma_{\mathrm{ss}}$ : 固溶強化量, $\sigma_{\mathrm{ppt}}$ : 析出強化量, $\sigma_{\mathrm{prlt}}$ ： パーライトによる強化量, $\sigma_{\mathrm{dis}}$ : 転位強化量, $K$.

$d^{-1 / 2}\left(\sigma_{\mathrm{gr}}\right)$ : 細粒強化量, $\sigma_{\mathrm{yo}}$ : 定数(パイエルス力) 機構別強化量の数式化は低炭素鋼領域に主眼が置かれ たものとして主に PICKERING ら〕8) により，また中 · 高炭素鋼に対しては GLADMAN ら9)により検討がなされ ている.それらを含めて従来得られている結果を Table 2 にまとめて示す10) 14)。前記二者の数式においては主 に細粒強化の扱いが異なつている．本実験で用いた炭素 鋼に対して両者の式を比較検討したところ，いずれの式 によつても実験值との適合性に大差は認められなかつた ものの，係数 $K=$ 一定とした方が中炭素鋼領域に対して もむしろ良い関係を与えた。なお，計算式の中でパーラ イトによる強化量 $\sigma_{\mathrm{pr} 1 \mathrm{t}}$ はラメラー間隔 $S_{0}$ およびフェ ライト体積分率 $f_{\alpha}$ の関数となつているが， $S_{0}$ は電顕 観察による垁測平均值として $0.5 \mu \mathrm{m} ， f_{\alpha}$ は実験式とし $\tau$

$$
f_{\alpha}=1-1.18 \times(\% \mathrm{C})
$$

をそれぞれ与えた. 定数 $a$ については最も良い関係を与 えるとされている $a=1 / 3$ を用いた. Pickering の示し た式7)8）による計算值と実測值の関係を Fig. 5 (a) に 示す. open mark で示される炭素鋼に対しては比較的良 い一致を示すといえるが solid mark で示される析出強 化を含むものはかなり高目に評価される傾向を示す.

析出強化量は Table 2 に示される Kocks の式 ${ }^{11)}$ みられるように析出物の体積分率と粒寸法とにより関係 づけられる. しかしながら，それらを正確に求めること は困難であるので，ここでは央験式により析出強化量の 適正な評価を行らことにした。Fig. 6 は $0.02 \% \mathrm{Nb,}$ $0.1 \% \mathrm{~V}$ 添加鋼のフェライト粒径補正後の析出強化量を 
Table 2. Summary of quantitative analysis of strengthening mechanisms for YS.

\begin{tabular}{|c|c|c|c|c|}
\hline Reference & $\begin{array}{l}\text { Solid solution } \\
\sigma_{\mathrm{ss}}: \mathrm{kgf} / \mathrm{mm}^{2}\end{array}$ & $\begin{array}{l}\text { Precipitation } \\
\sigma_{\mathrm{ppt}}: \mathrm{kgf} / \mathrm{mm}^{2}\end{array}$ & $\begin{array}{c}\text { Pearlite } \\
\sigma_{\mathrm{prlt}}: \mathrm{kgf} / \mathrm{mm}^{2}\end{array}$ & $\begin{array}{c}\text { Grain refinement } \\
K \times d^{-1 / 2}: \mathrm{kgf} / \mathrm{mm}^{2}\end{array}$ \\
\hline PICKERING 7 ) 8) & $\begin{aligned} 8.5 \mathrm{Si}+3.3 \mathrm{Mn} & \\
& +36.1 N_{\mathrm{f}}\end{aligned}$ & $\begin{array}{l}153 \times(\mathrm{V} \text { or } \mathrm{Nb}) \\
\quad(\text { average })\end{array}$ & $\begin{array}{c}\left(18.2+0.39 S_{0}^{-1 / 2}\right) \\
\times\left(1-f_{\alpha}^{a}\right)\end{array}$ & $1.77 d^{-1 / 2}$ \\
\hline $\begin{array}{l}\text { GLADMAN, MCIVOR and } \\
\text { PICKERING } 9 \text { ? }\end{array}$ & $\begin{aligned} 6.4 \mathrm{Si}+5.9 & f_{\alpha}{ }^{1 / 3} \mathrm{Mn} \\
& +42.8 V N_{\mathrm{f}}\end{aligned}$ & - & $\begin{array}{c}\left(18.2+0.39 S_{0}^{-1 / 2}\right) \\
\times\left(1-f_{\alpha}^{a}\right)\end{array}$ & $1.77 f_{\alpha}{ }^{1 / 3} \times d^{-1 / 2}$ \\
\hline Grozier $^{5)}$ & $7.2 \mathrm{Si}+4.1 \mathrm{Mn}+$ others & - & $0.154(\%$ pearlite $)$ & $1.65 d^{-1 / 2}$ \\
\hline IRVIN ${ }^{10)}$ & $8.5 \mathrm{Si}+3.3 \mathrm{Mn}$ & - & - & $1.76 d^{-1 / 2}$ \\
\hline $\operatorname{Kocks}^{11)}$ & - & $\begin{array}{l}6.0 \times 10^{-4} \times(V / f) / \bar{x} \\
\times \ln \left(\bar{x} \times 10^{7} / 2.5\right)\end{array}$ & - & - \\
\hline $\mathrm{KANAGAWA}^{12)}$ & $9.6 \mathrm{Si}+2.2 \mathrm{Mn}+$ others & - & - & $1.23 d^{-1 / 2}$ \\
\hline $\begin{array}{l}\text { KLESNIL, HoLZMANN } \\
\text { et al. 13) }\end{array}$ & - & - & - & $1.92 d^{-1 / 2}$ \\
\hline ҮоковоRI ${ }^{14}$ & - & - & - & $2.36 d^{-1 / 2}$ \\
\hline
\end{tabular}

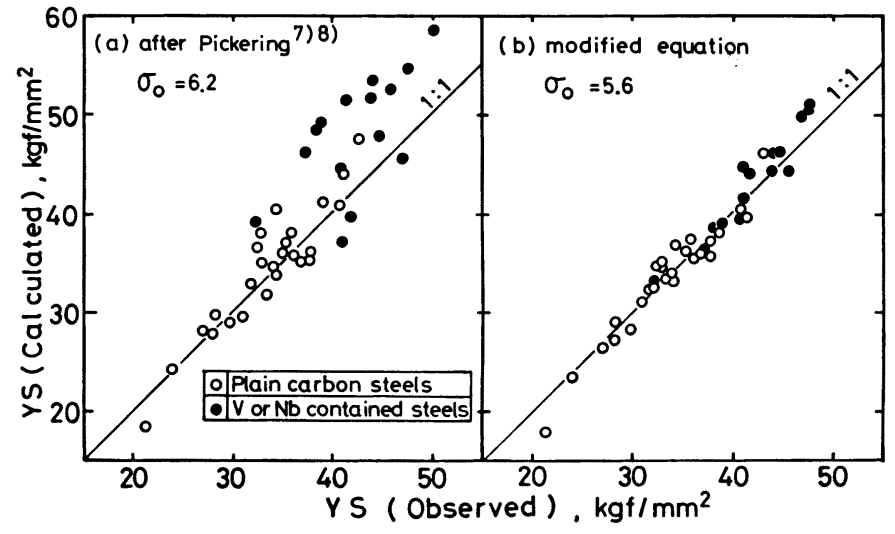

Fig. 5. Comparison between observed yield stress and calculated one.

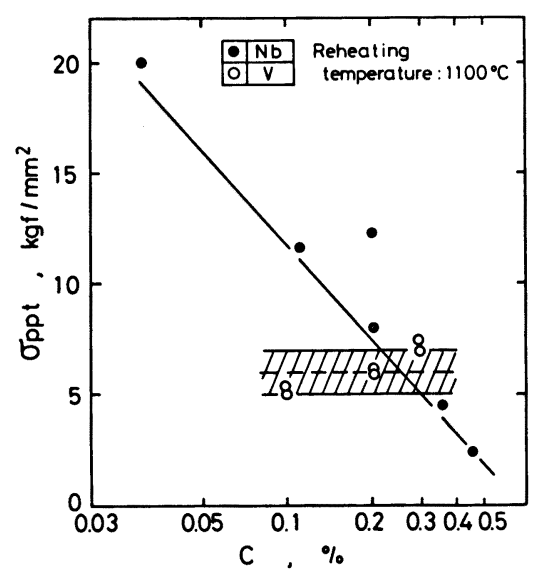

Fig. 6. Relation between carbon content and increment of yield stress by precipitation strengthening in $\mathrm{Nb}$ or $\mathrm{V}$ contained steels.
炭素量との関係として表したものである。これより $\mathrm{Nb}$ 添加鋼に拈いては炭素量の増加とともに析出強化量の減 少が，一方 V添加鋼の場合は炭素量によらずほぼ一定の 析出強化量を示すことが認められる. $\mathrm{Nb}$ 添加鋼の場合 は $\mathrm{Nb}(\mathrm{CN})$ による析出が生じていると考えられ, 炭素 量の増加に伴い加熱時の溶解度が減少し結果的に析出強 化量の低下が生じていると思われる. 一方, V添加鋼に おいてはVN による析出強化が主体であり炭素量の影 響を受けない結果となつていると考えられる.

Fig. 6 より本研究で用いた鋼種の析出強化量は (3) 式の形で与えられる.

$$
\left.\begin{array}{rl}
\sigma_{\mathrm{ppt}}\left(\mathrm{kgf} / \mathrm{mm}^{2}\right)= & -14.4 \log (\% \mathrm{C})-2.8 \\
\ldots \ldots \cdots \mathrm{Nb} \text { contained } \\
(0.03 \leqq \mathrm{C} \leqq 0.5) \\
=6.0 \\
\cdots \cdots \cdots \mathrm{V} \text { contained }
\end{array}\right\}
$$


析出強化量を( 3 )式により, 他の強化量については $\mathrm{PI}_{\mathrm{I}}$ CKERING の式により計算した值を実測值と比較してFig. 5 （b）に図示する.PICKeRING の式を一部修正するこ とにより本鋼種に適した数式化が得られたことが示され ている.

\section{4. 考察}

\section{$4 \cdot 1$ 疲労特性の強化機構別検討}

疲労特性は YS，TS といつた静的強度と直接に関係 づけられるものではなく本質的には強化機構別に分類し 検討する必要のあることが前章の結果から示唆された. そこで, 疲れ限度について強化機構別に分類し最終的に 次の (4)式の形で表すことを試みる。すなわち，(4)式 の係数 A〜Eが異なるものと考学，これを決定すること によつて各強化機構の疲労特性への寄与の程度を明らか にしようとするものである.

$$
\begin{aligned}
\sigma_{\mathrm{w}}=\sigma_{\mathrm{wo}}+A \cdot \sigma_{\mathrm{ss}}+B \cdot \sigma_{\mathrm{ppt}} & +C \cdot \sigma_{\mathrm{prlt}}+D \cdot \sigma_{\mathrm{dis}} \\
& +E \cdot\left(K \cdot d^{-1 / 2}\right) \cdots
\end{aligned}
$$

まず初めに俰数 $E$ を決定するため制御圧延あるいは焼 ならしにて粒径を調整した場合の結果から細粒強化量の 変化と疲労特性の相関を調べた。なお，前記処理による フェライト粒径以外の組織因子変化は無視し得るもので あつた. Fig. 7 飞細粒強化量 $\sigma_{\mathrm{gr}}=1.77 \times d^{-1 / 2}$ と疲れ 限度 $\sigma_{\mathrm{w}}$ の関係を表す．同図より両者の間には

$\sigma_{\mathrm{w}}\left(\mathrm{kgf} / \mathrm{mm}^{2}\right)=\sigma_{\text {wo }}{ }+0.43 \sigma_{\mathrm{gr}}$

$\sigma^{\prime}{ }_{\text {wo }}$ : 他強化機構によりもたらされる $\sigma_{\mathrm{w}}$ の 向上量 なる関係式が与兄らる。すなわち，細粒強化による YS の増加は俰数 0.43 で疲れ限度の向上に結びつくこ とを表す。

さて，Fig. 7 にみられる鋼種間の差異は粒径以外の

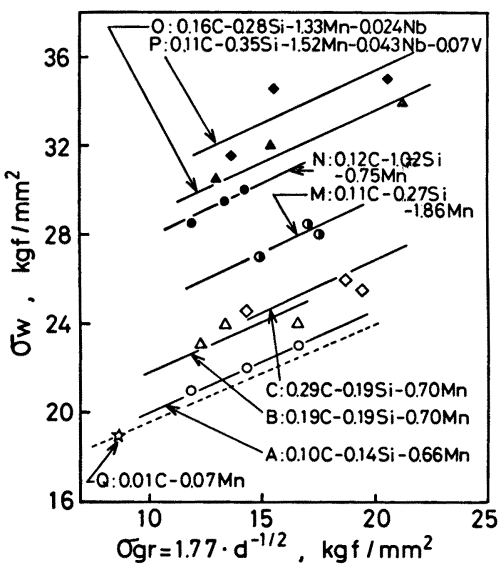

Fig. 7. Relation between increment of yield stress by grain refinement and fatigue limit.
因子であるパーライト量, 固溶・析出強化量の相違によ り説明されるべきものである。そこで，他の強化機構に ついても同様の手法で疲れ限度への影響を調べた。

炭素量を変化させパーライトによる強化量を調整した 場合にはパーライト量とともにフェライト粒径にも差異 が生じたためその影響を除く目的で以下の補正を行つ た.すなわち，Fig. 7 中に破線で示される工業用純鉄 （パーライト量 $=0$ ）を基準線としこの基準線からの增加 量を疲れ限度の変化量 $\Delta \sigma_{\mathrm{w}}$ とした. このようにして求 めた炭素鋼の $\Delta \sigma_{\mathrm{w}}$ を静的強化量 $\sigma_{\mathrm{pr} 1 \mathrm{t}}$ と比較したのが Fig. 8 である. 同図よりパーライトによる静的強化量 $\sigma_{\mathrm{pr} 1 \mathrm{t}}$ 之疲労特性の変化には良い比例関係が認められ

$$
\Delta \sigma_{\mathrm{w}}\left(\mathrm{kgf} / \mathrm{mm}^{2}\right)=0.53 \sigma_{\mathrm{prlt}}
$$

なる関係式が与えられる。

このような方法で各々の強化機構について疲れ限度と の関係を求めた．その結果を Fig. 9 亿まとめて示す. 図中，央線で示されているのが本研究において強化量を

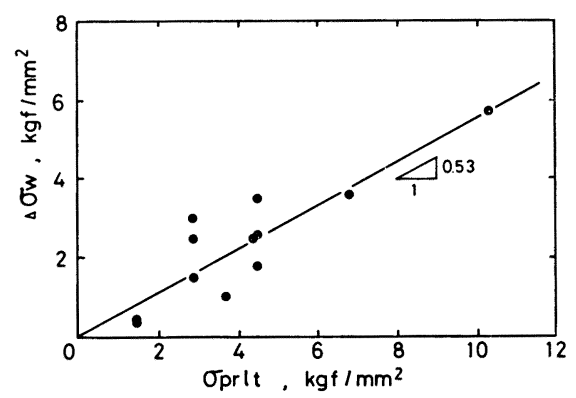

Fig. 8. Relationship between increment of yield stress and that of fatigue limit caused by pearlite strengthening.

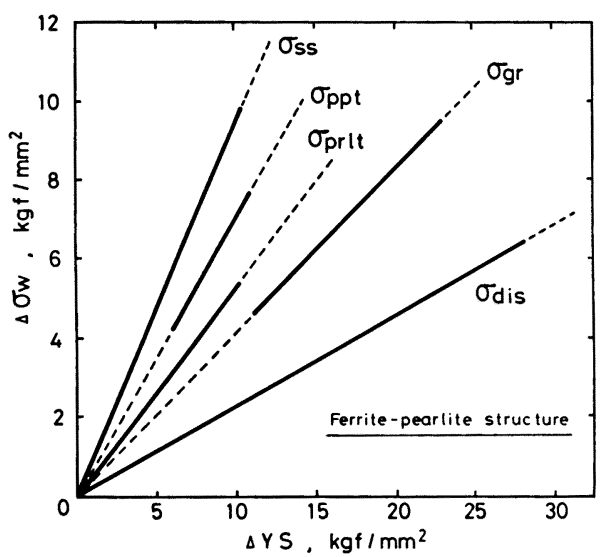

Fig. 9. Relationship between increment of yield stress $\Delta \mathrm{YS}$ and that of fatigue limit $\Delta \sigma_{\mathrm{w}}$ by each strengthening mechanism. 


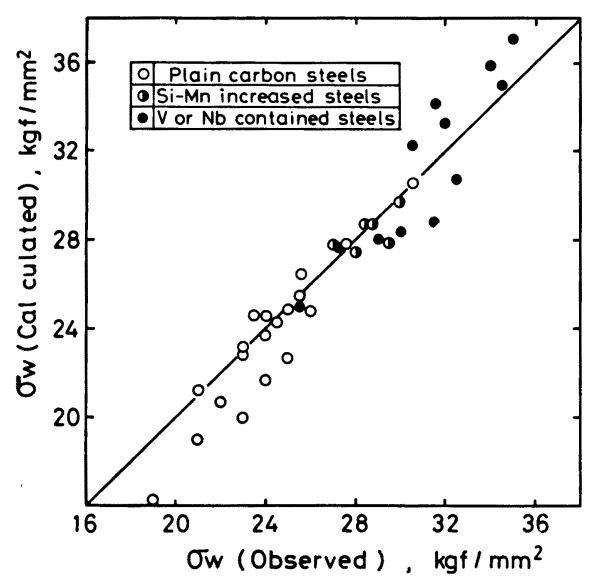

Fig. 10. Comparison between observed fatigue limit and that calculated by equation (7).

調整した範囲であり垁用上調整可能な範囲と考えられ る. 同図より, 同じ YS の増加量で比べた場合, 強化機 構により疲労特性への寄与が明らかに異なつていること が示されている.この結果から $\sigma_{\mathrm{w}}$ と各強化量との関係 として

$$
\begin{gathered}
\sigma_{\mathrm{w}}\left(\mathrm{kgf} / \mathrm{mm}^{2}\right)=8.4+0.92 \sigma_{\mathrm{ss}}+0.70 \sigma_{\mathrm{ppt}} \\
+0.53 \sigma_{\mathrm{prlt}}+0.43 \sigma_{\mathrm{gr}}+0.23 \sigma_{\mathrm{dis}} \cdots \cdots .
\end{gathered}
$$

が与えられる。（7)式により計算した值と笑測值はFig. 10 に示されるように良い一致をみている.

(7)式に表される係数值は各強化因子の疲労特性への 影響度を示したものと考えられるが，これより $\sigma_{\mathrm{ss}}>$ $\sigma_{\mathrm{ppt}}>\sigma_{\mathrm{prlt}}>\sigma_{\mathrm{gr}}>\sigma_{\mathrm{dis}}$ の順位で影響の程度の大小 が与 えられることがわかる. また，傾向的には係数が 0.70 ０.92 で示される固溶・析出強化，0.43 0.53 で表さ れるパーライト・細粒強化, さらに 0.23 の転位強化の

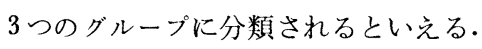

\section{2 疲れ過程との関連}

荒木4) は疲れの過程を（i 疲れ軟化損傷（ii）き裂の 発生（iii）き裂の伝ぱ,の 3 段階に分類しその中で疲れ軟 化損傷が微視的強化機構の影響を比較的強く受けるとし ている、すなわち, 繰り返し応力（ひずみ）による強化 構造の変化の難易により疲れ軟化損傷の程度が影響され るとし, 定性的には固溶強化あるいは安定な析出物によ る強化が優れていること, 逆に疲れによる強化機構の消 失が起こりやすい転位強化や転位の移動に伴つて消失す るような不安定な析出物による強化は影響が少ない15)こ とを示している.（7)式により与えられる定量的な結果 は上述の荒木らが示した定性的傾向と合致している.

Grozier 5 5) $\mathrm{Mn}, \mathrm{Si}$ ，パーライト体積分率等の個 別の因子と疲れ限度との関係として

$$
\begin{aligned}
& \sigma_{\mathrm{w}}\left(\mathrm{kgf} / \mathrm{mm}^{2}\right)=16.5+5.8(\% \mathrm{Mn})+10.1(\% \mathrm{Si}) \\
& +0.083(\% \text { Pearlite })+0.24\left(d^{-1 / 2}\right) \\
& +0.56 \Delta Y \\
& \Delta Y: \text { 析出強化量 }
\end{aligned}
$$

なる式を示している.（8) 式を Table 2 に示される GROZIER らの与えた強化量の計算式を利用し強化機構 別に変形すると

$$
\begin{aligned}
& \sigma_{\mathrm{w}}\left(\mathrm{kgf} / \mathrm{mm}^{2}\right)=16.5+(1.2 \sim 1.5) \sigma_{\mathrm{ss}}+0.56 \sigma_{\mathrm{ppt}} \\
& +0.54 \sigma_{\mathrm{prlt}}+0.13 \sigma_{\mathrm{gr}}
\end{aligned}
$$

が与えられる.（9)式の係数值を(7) 式で示される本研 究のものと比較すると順位の傾向は概略一致しているが 固溶強化の効果が 0.93 に比べ $1.2 \sim 1.5$ といつそう大 きく，また細粒強化の影響が 0.43 に対し 0.13 と低く 表されているのが大きな相違点である.

フェライト粒径と疲労特性の関係については横堀ら ${ }^{14)}$, KLESNIL ら ${ }^{13)}$ によても検討がなされており，それぞれ

$$
\sigma_{\mathrm{w}}\left(\mathrm{kgf} / \mathrm{mm}^{2}\right)=\sigma^{\prime}{ }_{\text {wo }}+1.24 d-1 / 2
$$

by Yoковоri et al.

$$
\sigma_{\mathrm{w}}\left(\mathrm{kgf} / \mathrm{mm}^{2}\right)=\sigma^{\prime}{ }_{\text {wo }}+0.48 d-1 / 2
$$

by KLESNIL et al.

なる関係式を与えている.さらに YS に対してはTable 2 中に表される関係をそれぞれ示しているのでこれを利 用して細粒強化量 $\sigma_{\mathrm{gr}}$ との関係として求めると

$\sigma_{\mathrm{w}}\left(\mathrm{kgf} / \mathrm{mm}^{2}\right)=\sigma^{\prime}{ }_{\text {wo }}+0.53 \sigma_{\mathrm{gr}}$

by YоковоRI et al.

$\sigma_{\mathrm{w}}\left(\mathrm{kgf} / \mathrm{mm}^{2}\right)=\sigma^{\prime}{ }_{\text {wo }}+0.25 \sigma_{\mathrm{gr}}$

by KLESNiL et al.

なる式が与えられる. 従つて細粒強化に対する係数は, $0.13 \sim 0.53$ の範囲で各研究により異なつている.これ は用いた成分系および粒径の調整方法の相違等などによ るものと考えられるが, 本研究で求めた係数值 0.43 は 従来示されていた範囲内の值となつている.

一方，固溶強化の影響に対しては GROZIER らの結果 は係数 $1.2 \sim 1.5$ と非常に高い值を示している. 交叉す ベりを抑制するような固溶強化が疲れ限度の向上に有効 に働くことは荒木ら4) の指摘するところである.しかし ながら, 疲れ限度の向上量が YS の増加量より上まわる といつたことは疲れ限度が YS を越えるといつた場合を 生じ不都合と思われる. 従つて, 係数值としては 1 以下 が適正であろらと考えられる.

さて, 疲労き裂の発生は繰り返し応力による表面への 転位の移動・集積が原因となつている ${ }^{16)}$. 既述した各強 化機構の疲れ限度に対する寄与の順位は転位の移動の難 易と対応していると考えられる．転位の移動の抑制に関 しては固溶・析出強化が転位の移動そのものを固着ある 
いはピンニング効果により防ぐのに対し, 細粒強化やパ ーライトによる強化は移動してきた転位の障害物となる ことで転位の移動を妨げるといら異なる働きを示す。す なわち, 固溶・析出強化の方がより本質的な意味で転位 の移動の抑制に有効に作用するわけで，このことが他強 化因子に比べ疲労特性の向上に対し寄与の高い一因であ ると考えられる.さらに, 疲労き裂が組織的に最も弱い 部分から発生する ${ }^{15)}$ といら機構を考えると比較的マトリ ックスを均一に強化するものが疲労特性に対し有利であ ると推察される. 前記強化因子が特性向上に有効である のは一つにはこのよらな理由によると思われる.

一方, 転位強化はセルの形成により転位の移動を阻害 するが転位密度の上昇に伴い可動転位密度も増加すると 考えられる. 他強化因子と比べ転位強化が疲労特性の向 上にそれほど有効に結びつかないのは疲れき裂の発生に 結びつく可動転位の増加によると考えられる.

以上のことからフェライト・パーライト組織であつて も固溶強化・析出強化を有効に利用すれば分散強化され た焼入れ焼もどし材と同等程度の疲れ特性を付与し得る ものであると考えられる. マイクロアロイングを基本と する非調質型機械構造用棒鋼は上述の観点から圧延まま で調質材と同等の良好な疲労特性を有しているといえ る.

\section{5. 結言}

低・ 中炭素鋼の範囲で $\mathrm{V} \cdot \mathrm{Nb}$ の添加の有無, $\mathrm{Si} \cdot \mathrm{Mn}$ 量の調整等種々の成分を有する鋼種を用い, 静的強度と 疲労特性の関連を強化機構に分類して検討した結果以下 の結論を得た。

(1) 疲労特性は静的強度とは直接に関係づけられず 本質的にはYS を構成する各強化機構により影響され る.

(2) 疲れ限度 $\sigma_{\mathrm{w}}$ はフェライト・パーライト組織に おいて強化因子と次式で関係づけられる.

$\sigma_{\mathrm{w}}\left(\mathrm{kgf} / \mathrm{mm}^{2}\right)=8.4+0.92 \sigma_{\mathrm{ss}}+0.70 \sigma_{\mathrm{ppt}}$ $+0.53 \sigma_{\mathrm{prlt}}+0.43 \sigma_{\mathrm{gr}}+0.23 \sigma_{\mathrm{dis}}$

ここで, $\sigma_{\mathrm{ss}}$ : 固溶強化量, $\sigma_{\mathrm{ppt}}$ : 析出強化量 $\sigma_{\mathrm{pr} 1 \mathrm{t}}$ ：パーライトによる強化量, $\sigma_{\mathrm{gr}}$ : 細粒強化量

$\sigma_{\mathrm{dis}}$ : 転位強化量

（3）固溶・析出強化の疲労特性への寄与は他強化因 子に比べ比較的高い. 疲れき裂発生の前段階は綝り返し 応力による表面への転位の移動・集積であるが固溶・析 出強化はこの転位の移動の抑制に対し有効に作用し, か つ比較的マトリックスを均一に強化することにより疲労 特性向上に対する寄与が大きいものと考えられる。

（4）マイクロアロイングを基本とした非調質型機械 構造用棒鋼は上述の観点から圧延ままのフェライト・ハ ーライト組織において分散強化された調質材と同等の良 好な疲労特性を有していると考えられる.

\section{文献}

1) 阿部隆, 三桼折也, 大铃弘忠, 大内干秋, 城户 弘, 杉本 悟: 鉄と鋼, 68 (1982), S 472

2) 四代胃一：鉄鋼基礎共间研究会微量元素部会 V 研 究会共同研究報告書（1970 年7月）［日本鉄鋼協 会]

3 ) 小林光征, 山本優, 宮川大海: 日本機械学会論 文集，43 (1977)，p. 2803

4 ) 荒木 透：日本金属学会会報， 17 (1978), p. 711

5 ) J. D. Grozier and J.H. Bucher: Journal of Materials, 2 (1967), p. 393

6 ）西島 敏：金材技研疲れデータシート资料 1 (1981) [金属材料技術研究所]

7 ) F. B. Pickering: Hardenability Concepts with Applications to Steel, ed. by $D . V$. DOANE (1978), p. 179 [AIME]

8 ) F. B. Pickering: Micro-alloying '75, Proc. of Int. Conf. on HSLA Steels (1977) [Union Carbide Corp.]

9 ) T. Gladman, I. D. MaIvor and $F . B$. Pickering: JiSI, 210 (1972), p. 916

10) $K . J$. Irvine: Strong Tough Structural Steels (1967), p. 1 [ISI]

11) U. F. Kocks: Phil. Mag., 13 (1966), p. 541

12）金沢正午：鉄鋼基礎共问研究会微量元素部会 $\mathrm{Nb}$ 分科会共同研究報告書（1969 年11 月）［日本鉄鋼 協会]

13) $M$. Klesnil, $M$. Holzman, $P$. Lukáš and $P$. Ryš: JISI, 203 (1965), p. 47

14) 横堀武夫：材料強度学 (1974), p. 300[岩波書店]

15）国尾 武, 清水真佐男, 榎本雅己: 材料, 26 (1977), p. 901

16）例党ば，幡中慧治，山四敏郎：材料，25(1976), p. 1143 